\title{
Near-zero humidities on Ben Nevis, Scotland, revealed by pioneering 19th- century observers and modern volunteers
}

Article

Accepted Version

Burt, S. and Hawkins, E. (2019) Near-zero humidities on Ben Nevis, Scotland, revealed by pioneering 19th-century observers and modern volunteers. International Journal of Climatology, 39 (11). pp. 4451-4466. ISSN 0899-8418 doi: https://doi.org/10.1002/joc.6084 Available at https://centaur.reading.ac.uk/82775/

It is advisable to refer to the publisher's version if you intend to cite from the work. See Guidance on citing.

To link to this article DOI: http://dx.doi.org/10.1002/joc.6084

Publisher: John Wiley \& Sons

All outputs in CentAUR are protected by Intellectual Property Rights law, including copyright law. Copyright and IPR is retained by the creators or other copyright holders. Terms and conditions for use of this material are defined in the End User Agreement.

www.reading.ac.uk/centaur 
Central Archive at the University of Reading

Reading's research outputs online 


\title{
Near-zero humidities on Ben Nevis, Scotland, revealed by pioneering nineteenth-century observers and modern volunteers
}

\author{
By Stephen Burt and Ed Hawkins \\ Department of Meteorology, \\ University of Reading \\ ORCID ID (SB) 0000-0002-5125-6546 (EH) 0000-0001-9477-3677
}

\begin{abstract}
The weather on Ben Nevis - the highest mountain in the British Isles, $1345 \mathrm{~m}$ AMSL - sometimes shows episodes of remarkably low relative humidity (RH) with few precedents anywhere else in the British Isles. We are able to quantify this for the first time using a high-quality series of hourly dryand wet-bulb observations, made on the summit. These observations were made between 1883 and 1904, but have only just become available to modern science, thanks to thousands of volunteers who worked to rescue this unique and exemplary dataset from published volumes. Careful examination and analysis of the original observations using modern psychrometric theory revealed several occasions where we are confident that the summit RH fell close to zero as a result of anticyclonic subsidence. Three case histories are examined in some detail. The nineteenth-century Ben Nevis humidity records are also compared with contemporary automatic weather station (AWS) data from two high-altitude Scottish mountain sites.
\end{abstract}

\section{Keywords}

Ben Nevis; relative humidity; anticyclonic subsidence; psychrometric calculation; crowdsourcing; Scotland; Cairngorm; Aonach Mor

\section{Why investigate occasions of very low humidity?}

Knowledge of the amount of water vapour in the air, whether measured directly or derived from indirect methods, remains one of the most important parameters in meteorology, whether in climatological studies or in forecast models. Determination of both the average and the range of variation in moisture content is essential for many climatological studies, particularly so for extremes, as prolonged periods of very high humidity (saturated air) or very low humidity are disadvantageous to both human and plant health. Occasions of very low RH (below 20\%) are infrequent in temperate climates, and their rarity warrants investigation of the circumstances under which they occur. Low humidities at mountain sites in the United Kingdom have previously been documented by Green (1953 \{, $1953 \# 490\}, 1965$ \{, $1965 \# 477\}, 1966$ \{, $1966 \# 488\}, 1967$ \{, 1967 \#320\}) and Burt (2011).

\section{The Ben Nevis Observatory: background and data sources}

The International Meteorological Congress of Rome in 1879 set out the perceived necessity of establishing weather stations on mountain summits to assist in developing weather forecasting methods: this was of course many decades before upper-air data became routinely available through 
balloon and radio-sounding methods. The first such high-level mountain observatory was Säntis in north-east Switzerland at $2502 \mathrm{~m}$ above Mean Sea Level (AMSL), where records commenced in 1882 (and continue today). A mountain site in western Scotland was seen to be particularly important owing to its position within the main cyclonic storm track affecting north-west Europe, and Ben Nevis was the obvious choice as both the highest mountain in the British Isles and by virtue of relatively easy access to the summit. Funds were quickly raised by public appeal, and a staffed observatory was established on the summit at $1345 \mathrm{~m}$ AMSL by the Scottish Meteorological Society in October 1883 (Figure 1). Hourly observations of pressure, screen temperature (dry- and wet-bulb), wind speed and direction, precipitation, sunshine, cloud amount along with regular observations of present weather types, snow depth and other phenomena (such as thunderstorms, aurora, glories etc) were made there and communicated by telegraph link to Fort William, less than $10 \mathrm{~km}$ north-west of Ben Nevis as the crow flies (Buchan 1890, (Buchan and Omond) 1902, Omond 1910, Duncan 1983, McConnell (1988a); (McConnell 1988b): for a recent account of the Observatory's history, see Roy, 2004). Contemporary photographs of the observatory are shown in Figures 2 and 3. A similar observatory was established near sea level in Fort William, to provide simultaneous near-vertical observations throughout the depth of the lowest part of the atmosphere.

Summit weather was frequently atrocious, and observations were often made under difficult or even hazardous circumstances by a small team of dedicated observers. The generation of the records and their survival in published volumes remains a lasting tribute to their dedication, and indeed to the Scottish Meteorological Society itself (which amalgamated with the Royal Meteorological Society in 1921).

Throughout its existence, Ben Nevis Observatory received almost no public funding, and following several years of financial deficits both observatories were closed in October 1904. The records from both Ben Nevis and Fort William observatories were published in full in the Transactions of the Royal Society of Edinburgh in four large volumes (Buchan 1890, Buchan and Omond 1902, Buchan and Omond 1905, Omond 1910). However, relatively little use has been made of them since the final volume was published in 1910. In 2017, a project to digitise the published records from the two observatories (by now scanned and available online) resulted in the setting-up of a citizen science Zooniverse website weatherrescue.org. The enthusiastic response of more than 3000 volunteers resulted in the creation of a digital database of close to two million records in just 10 weeks. The database has been quality-controlled and researcher access is freely available; the creation and structure of the database are set out in Hawkins et al (2019).

The Ben Nevis Observatory records, consisting of more than 20 years of meticulous manned hourly observations from the highest point in the British Isles made with the best available instruments of the period, constitute without doubt the ultimate British mountain weather dataset. Modern unmanned automatic weather stations (AWS) on other Scottish mountains such as Cairngorm (1245 m AMSL) have provided valuable insights into upland weather conditions (see, for example, Curran et al. (1977), Barton (1984) and http://cairngormweather.eps.hw.ac.uk), and more recently Kendon and Diggins (2019\{, \#1456@@hidden\}), but the severity of the climate and frequent riming make for an extremely difficult operating environment and there are occasional breaks in record as a result. Plans are being made to install a modern, severe-weather capable AWS on Ben Nevis, but these are at an early stage, provision of a stable power supply being one of the main obstacles (the output of solar panels being severely reduced in the riming conditions which frequently prevail on the mountain).

\section{Calculating humidity}

During the years when the Ben Nevis Observatory was operational, values of relative humidity $(\mathrm{RH})$ were derived by the observers from published humidity tables. Initially, tables prepared empirically for general-purpose use (not specifically for a high-level observatory) from investigative work undertaken at low-level observatories in London (for example, Glaisher's tables from Greenwich 
Observatory - Glaisher 1869 - and similar) were used. The tables made no allowance for reduced atmospheric pressure at altitude (resulting in values of $\mathrm{RH}$ that were too $\mathrm{low}^{1}$ ), and although adequate for the conditions of near-saturation that often prevailed, the tables were inadequate for the extremes of both low temperature and low humidity occasionally experienced on Ben Nevis. Extrapolation beyond their normal range was frequently resorted to and 'extended' tables drawn up. Work was undertaken at the Observatory in 1885 to compare dew point temperatures derived from dry- and wetbulb readings using such tables with those measured directly using an early mirror-cell hygrometer by Chrystal (Dickson 1885); the conclusion was that the tables in use were increasingly in error under certain conditions which occurred much more frequently at the high-level observatory than nearer sea level. The lack of agreement with humidity tables was perhaps fortunate in retrospect, in that the decision was made when the records were eventually prepared for publishing to document the observed readings of both dry- and wet-bulb thermometers, rather than the dry-bulb and relative humidity derived from contemporary tables.

Dry- and wet-bulb thermometers (whether traditional liquid-in-glass units, or electrical resistance devices such as platinum resistance thermometers) offer a reliable, tried-and-tested method for determining $\mathrm{RH}$ to acceptable accuracy within a wide range of conditions, specifically when the wetbulb temperature is above $0{ }^{\circ} \mathrm{C}$ and the $\mathrm{RH}$ is greater than about 20-25\%. Outside these limits, the use of a modern properly calibrated capacitance sensor generally provides more consistent and repeatable measurements (see, for example, Burt (2011) for another case history of an extremely low RH event in Cumbria in 2011), and it is advisable to exercise caution when using records of dry- and wet-bulb temperature to determine RH in such cases. The subject is covered in more detail elsewhere: see Burt (2012) Chapter 8, Harrison (2014) Chapter 6 or World Meteorological Organization (World Meteorological Organization (WMO) 2014) for more detail, but briefly:

- It is difficult to maintain a 'wet' wet-bulb thermometer at very low RH, because water loss from evaporation can exceed replacement through capillary action to the wet-bulb muslin 'sock';

- The increased response time owing to the insulation of the muslin 'sock' on the wet-bulb can lead to significant lag, particularly where temperatures are changing rapidly;

- The bulb and muslin can remain wet for long periods even when the wet-bulb temperature falls below $0{ }^{\circ} \mathrm{C}$, if the temperature does not fall very far. Below typically about $-3^{\circ} \mathrm{C}$, sometimes lower, the muslin will freeze, at which point the wet-bulb temperature will rapidly rise to $0.0{ }^{\circ} \mathrm{C}$ owing to the release of latent heat, and remain there for several minutes (a useful calibration check) before as quickly falling back to the pre-freezing temperature, now known as the 'ice-bulb temperature'. However, it is almost impossible to maintain a continuous 'ice-bulb' (a frozen wet-bulb) at low RH, owing to the cessation of capillary action. The published observatory records do, nevertheless, record the care and attention given to establishing and maintaining the 'ice-bulb' at and between hourly observations (Buchan (1890), pp xxx-xxxi), and we can be sure this was managed as closely as was possible in often extreme circumstances;

- The phase change from ice to liquid water when a frozen wet-bulb warms through $0{ }^{\circ} \mathrm{C}$ often results in the wet-bulb 'sticking' at $0.0^{\circ} \mathrm{C}$ owing to latent heat extraction. If the dry-bulb continues to warm without hindrance, this results in an artificially large depression of the wetbulb and thus an unrealistic (low) RH until the phase change is complete - which, in conditions close to $0{ }^{\circ} \mathrm{C}$, can take hours;

\footnotetext{
${ }^{1}$ The psychrometric equations (see following section) show that the difference between calculated and true ambient RH increases with decreasing ambient pressure and decreasing humidity. A $150 \mathrm{hPa}$ decrease in barometric pressure would reduce a derived $\mathrm{RH}$ of $10 \% \mathrm{RH}$ to close to zero at the typical air temperatures prevailing on Ben Nevis, and result in physically impossible sub-zero RH derivations in drier air.
} 
- The derived RH is critically dependent upon wet-bulb ventilation - more on this point subsequently, but a minimum ventilation of about $1 \mathrm{~m} \mathrm{~s}^{-1}$ is necessary for confidence in the result;

- Solar heating of the Stevenson screen containing the dry- and wet-bulb thermometers can result in slight additional warming relative to the true air temperature, particularly in light winds (Herbertson 1905). Usually, the increase in the wet-bulb temperature will be greater than that of the dry-bulb, and the derived RH may be substantially higher than the true (ambient) value.

Hourly values of RH were calculated using the following approach. Firstly, the saturation vapour pressure at the dew point $e$ was calculated from the psychrometric equation (Harrison (2014):

$$
e=e_{s}(\text { Twet })-A p(\text { Tdry }- \text { Twet })
$$

... where Tdry and Twet are respectively the dry- and wet-bulb temperatures, $e_{s}($ Twet $)$ is the saturation vapour pressure at Twet, $A$ is the psychrometric coefficient, $p$ is the station-level pressure in $\mathrm{hPa} / 1000$, and (Tdry-Twet) is the difference in $\mathrm{K}$ between the readings of the dry- and wet-bulb thermometers (this term is referred to as the 'depression of the wet-bulb').

The saturation vapour pressure $e_{s}$ at any particular temperature $T{ }^{\circ} \mathrm{C}$ was then obtained from the following expression (Bolton 1980):

$$
e_{s}=6.112 \exp (17.67 \mathrm{~T} / T+243.5)
$$

for temperatures $T^{\circ} \mathrm{C}$ above $0{ }^{\circ} \mathrm{C}$, and

$$
e_{s}=6.109 \exp (22.5 T / T+273)
$$

for temperatures $T^{\circ} \mathrm{C}$ below $0{ }^{\circ} \mathrm{C}$.

Finally, the relative humidity RH is given by

$$
\mathrm{RH}=e / e_{s}
$$

... usually expressed as a percentage.

The Ben Nevis Observatory humidity dataset was calculated from observed and published hourly values of Tdry and Twet (converted from ${ }^{\circ} \mathrm{F}$ to ${ }^{\circ} \mathrm{C}$, and following quality control checks as set out in Hawkins et al, 2019) and station-level pressure (converted from inches of mercury to $\mathrm{hPa}$ ). The value of $A$ varies significantly with ventilation, however. Figure 4, from Harrison (2012), shows that for ventilation $\geq 1 \mathrm{~m} \mathrm{~s}^{-1}, A$ is close to 0.7 . For ventilation below about $1 \mathrm{~m} \mathrm{~s}^{-1}, A$ is somewhat higher. The difficulty here is assessing the likely ventilation through the Stevenson-type screens used at the Observatory for each observation; as a proxy (and in the absence of any published studies), it was assumed that screen ventilation was half of the observed hourly wind speeds. At the Ben Nevis Observatory, wind speeds were estimated hourly on the 0-12 Ben Nevis scale (wind speeds were estimated because conventional cup anemometers were unusable in the severe riming conditions prevailing on the summit for much of the year). An equivalence table from the estimated wind force to miles per hour was derived from comparison with cup anemometer records during a few summer months and published (Buchan and Omond 1905), p 483). Most often, a range of forces was used for example, 1-3 - and in such cases the average of the two forces is held on the new digital dataset. The scale was not linear, and a polynomial expression was used from the published equivalence table to derive observed wind speed in metres per second: more details are given in Hawkins et al (2019). Table 1 gives the values of $A$ used here for the purposes of the psychrometric equation. 


\section{The Ben Nevis humidity record}

For the entire period of published summit observations, December 1883 to September 1904 inclusive, the RH was calculated using the method above for every hourly observation with a valid dry- and wetbulb combination - in all, in excess of 180,000 observations. Many wet-bulb observations were missing during the first winter, presumably because it took time to resolve operational difficulties in maintaining ice-bulbs during winter conditions at the summit; however, after early April 1884 the record is largely complete (including the occasional estimate) until the closure of the Observatory in September 1904. Hourly wind speeds were digitised only for the second half of the record (January 1893 onwards); where a wind speed record was not available, the hourly mean (Ben Nevis Force 2.1, approximately $7 \mathrm{~m} \mathrm{~s}^{-1}$ ) was used to suggest an appropriate value for $A$. Occasional RH values below zero were constrained to $0 \% \mathrm{RH}$ and (more frequent) values slightly above $100 \% \mathrm{RH}$ were similarly constrained to $100 \%$ (the difficulty of maintaining a 'dry' dry-bulb in the high humidity conditions prevalent on the summit are frequently referred to in the published logs). From this, a frequency table was constructed of hourly RH in 5 per cent bins. All observations with a calculated RH less than 10 per cent were re-examined and, where necessary, missing wind speeds added manually from the published observations, and the frequency table recalculated. Where station level pressure observations were missing or outside QC ranges, an average of all the remaining observations (856 hPa) was used in the hourly calculations. Table 2 shows the final table.

The results from Table 2 are plotted on a logarithmic scale in Figure 5 and compared with data for modern records of similar length (from automatic weather stations fitted with capacitance humidity sensors) at Aonach Mòr (1130 m AMSL, 3.5 km north-east of the old Ben Nevis Observatory summit site) and on Cairngorm Summit (1237 m AMSL, $91 \mathrm{~km}$ east-north-east of Ben Nevis; see Table 3 for site and record details for both locations). The profile of the Ben Nevis historical data in Figure 5 is strikingly similar to the modern records, the higher frequencies close to saturation likely a reflection of the summit being in cloud more frequently than the two slightly lower (and leeward) sites. (The profile agreement also strengthens confidence in the quality and accuracy of the Ben Nevis temperature and humidity dataset.) All three sites show a similar frequency of sub-10\% RH (2.0 observations per mille at Ben Nevis, 1.2 at Aonach Mòr and 2.6 at Cairngorm), notwithstanding differing record periods, data availability and measurement methods.

The climatological humidity profile for these three high-altitude sites is strikingly different from lowlevel sites. The fourth profile in Figure 5 is for a low-level site in central southern England (Stratfield Mortimer Observatory in Berkshire, $10 \mathrm{~km}$ south-west of Reading, $60 \mathrm{~m}$ AMSL) using a 25 year record 1993-2017, mostly from a capacitance RH sensor. Although conditions at high altitude in Scotland remain at or close to saturation for the great majority of observations, RH values below 35 per cent occur more frequently at altitude than at the lowland site, the relative frequency increasing with decreasing humidity. On the summit of Ben Nevis, $\mathrm{RH}$ values below $25 \%$ occurred on average eight times per thousand hours (about 73 hours per annum), compared with a (contemporary) annual average of less than 3 hours at or below 25\% in southern England.

\section{Occurrences of very low RH on Ben Nevis}

The occurrence of very low humidities on Ben Nevis has been previously documented. The published records themselves contain numerous descriptive accounts and some preliminary steps towards explanation, although true dynamical understanding in terms of anticyclonic subsidence was still some decades away. Green (1966) investigated several examples from the published record, but the availability of the records only in hardcopy format and the lack of modern digital data-processing methods meant that only a few instances could be examined in detail. The recent digitisation of the entire record enables a better understanding of the frequency of such events and a wider examination of the circumstances surrounding them. 
From the assembled dataset covering April 1884 to September 1904, 49 dates (223 hours in all) were identified when the (recalculated) RH had fallen to $5 \%$ or less for at least one hourly observation at the Ben Nevis Observatory. These are listed in Table 4, together with detail of mean wind speeds and temperatures for the relevant periods (some are single hour entries). Table 5, Table 6 and Table 7 provide a breakdown of the frequency (number of observation hours) of RH below $5 \%$ by air temperature and wind speed, by month and by hour of day, respectively. During the available period of record, such occurrences were most frequent in late winter and early autumn, but are dominated by a few relatively lengthy spells. Very low humidities were not limited to a narrow range of dry-bulb temperatures, events in Table 4 ranging from $-7{ }^{\circ} \mathrm{C}$ to $13{ }^{\circ} \mathrm{C}$. Station level pressure is not shown in Table 4, but the average for the events listed was well above normal $(870 \mathrm{hPa}$, all-events average 856 $\mathrm{hPa}$ ), indicative of a link with anticyclonic conditions. There is a suggestion of a diurnal variation (afternoon minimum, very broadly similar to the mean diurnal variation of wind speed on the summit), but the effect is small: a possible physical explanation here could involve greater turbulence (and thus entrainment from drier air above the summit) owing to the nocturnal jet. Warming of the screen in sunshine, increasing both dry- and wet-bulb temperatures but with a greater effect on the wet-bulb temperature (thus increasing the calculated $\mathrm{RH}$ ) may also have some impact.

\section{OCCURRENCES AT LOW WIND SPEEDS}

The majority of the occasions of very low RH (193 of the 223 hours listed in Table 4, 87 per cent) occurred with mean wind speeds during the spell of $1 \mathrm{~m} \mathrm{~s}^{-1}$ or less. Unfortunately, the uncertainty associated with such low ventilation rates through the Stevenson screen makes it difficult to assign a firm value to $A$, as a result of which the calculated RH is poorly constrained under those circumstances (this limitation was also pointed out by Townsend (1967), commenting on Green's 1966 paper). In 124 of these 193 hours (64\%) the calculated RH was below zero, a physically impossible result. However, by explicitly assuming that the ambient humidity was in low single digits we can evaluate the range of values of $A$ necessary to obtain $\mathrm{RH}=0 \%$ (the minimum value of $A$ ) or $\mathrm{RH}=5 \%$ (taken as a nominal low RH value), and compare them with the range of values shown on Figure 4.

By rearranging equation 3 above, the value of $A$ required to produce RH exactly zero (the minimum possible value of $A$, necessarily assuming zero error in thermometer and barometer readings) can be easily calculated, namely

$$
A=e_{s}(\text { Twet }) / p(\text { Tdry }- \text { Twet }) \quad \text { at } 0 \% \mathrm{RH}
$$

.. and similarly for $5 \% \mathrm{RH}$.

The subset of 124 hours with an observed wind speed of $1 \mathrm{~m} \mathrm{~s}^{-1}$ or less which resulted in a calculated $\mathrm{RH}$ below zero yielded minimum values of $A$ (for $\mathrm{RH}=0 \%$ ) and 'plausible' values of $A(\mathrm{RH}=$ nominal 5\%) as shown in Table 8. Although this necessarily involves somewhat circular logic, the values of $A$ are well within the scope of Figure 4, and are consistent with a mean ventilation through the Observatory screen in light wind conditions of approximately $0.2-0.3 \mathrm{~m} \mathrm{~s}^{-1}$, or about half of the observed mean wind speed during these spells. Within the limits of the century-old dataset, the agreement and fit is surprisingly good, and it seems plausible to claim that the summit humidity was very close to zero on these occasions. However, a more exact determination would require finer resolution of both surface wind speed and in-screen ventilation during these events, neither of which are ever likely to become available. For this reason, more attention has been focused on occasions when the ventilation was greater than $2 \mathrm{~m} \mathrm{~s}^{-1}$, as this is the approximate lower limit of wind speed sufficient to ensure at least $1 \mathrm{~m} \mathrm{~s}^{-1}$ ventilation through a Stevenson screen.

OCCURRENCES AT WIND SPEEDS OF $2 \mathrm{M} \mathrm{S}^{-1}$ OR MORE

Of the 223 hours with RH $\leq 5 \%$, only 30 had wind speeds of $2 \mathrm{~m} \mathrm{~s}^{-1}$ or greater (Table 4 and Table 5). With greater ventilation comes greater confidence in the value of $A$; only one of these 30 hours 
resulted in a recalculated $\mathrm{RH}$ below $0 \%$. These 30 events also ranged across a wide range of air temperatures, although the depression of the wet-bulb required for such low humidities ensured that the wet-bulb was below $0{ }^{\circ} \mathrm{C}$ in all but one. In the majority of these events the wet-bulb was below $-3{ }^{\circ} \mathrm{C}$ and, as such, would probably consist of an ice-bulb with consequent limitations on the supply of water available through capillary action. Without careful manual attention to moistening the wet/ice-bulb in good time before the observation, this would result in higher wet-bulb temperatures (i.e. closer to the dry-bulb) and thus artificially high derived humidity readings; fortunately there is ample evidence in the published accounts (see, for example, Buchan (1890), pp. xxx-xxxi) that great care was taken in such conditions.

\section{Case studies}

Three examples were chosen to illustrate summit conditions during extended periods of low humidity when strong winds provided sufficient ventilation to assume confidence in psychrometric calculations. The three spells detailed here account for one-third of the duration of all spells with RH at or below $5 \%$.

\section{EXAMPLE 1: 10 SEPTEMBER 1894}

Scotland lay to the north of an anticyclone centred over the Irish Sea; Figure 6 shows the synoptic situation at 1200 GMT from the 20th Century Reanalysis (Compo et al, 2011) and Figure 7 is a time series of hourly wind speeds and calculated RH from the Ben Nevis Observatory over 9-10 September 1894. This occasion was also one of those examined by Green (1966).

Skies were cloudless throughout 9 September and into the early hours of 10 September. Cloudier conditions prevailed from before dawn until late morning (cloud cover was unbroken at 0800 GMT) on 10 September, after which cloud cleared to $10 \%$ or less until after 1600 GMT; the summit was enveloped in cloud by 2100 GMT. During 9 September winds were light north to north-easterly during the morning, veering progressively during the day to southerly by late afternoon and westerly by midnight, and freshening somewhat; during 10 September winds were mostly between west and north-west, increasing irregularly during the day to average $16 \mathrm{~m} \mathrm{~s}^{-1}$ by evening. The RH began an irregular fall from 2000 GMT on 9 September as the wind became west-south-westerly. This decrease continued through the night and into the following day, the $\mathrm{RH}$ remaining at or below $20 \%$ for all but one of 16 consecutive hours from 0300 GMT, and below $10 \%$ for 10 consecutive hours. Throughout this period, mean winds varied between 6 and $16 \mathrm{~m} \mathrm{~s}^{-1}$, thus providing more than adequate ventilation through the Stevenson screen. At 1600 GMT on 10 September, the dry-bulb stood at $9.8^{\circ} \mathrm{C}$ and the wet-bulb $-0.1{ }^{\circ} \mathrm{C}$, leading to a calculated $\mathrm{RH}$ of $0.1 \%$. The wind at this time was north-westerly at $14 \mathrm{~m} \mathrm{~s}^{-1}$. Unusually, there are no comments specific to the day's weather or low humidity from the published Observatory logbook entries during this event, although the manuscript log book includes reference to the very dry air (Marjory Roy 2018, pers. comm.). At Fort William the RH exhibited a simple diurnal cycle, and the lowest observed RH was an unremarkable 57\%.

\section{EXAMPLE 2: 17-20 FEBRUARY 1895}

This spell occurred towards the close of one of the coldest spells in Scotland's recorded history, the temperature on the summit remaining below $0{ }^{\circ} \mathrm{C}$ continuously from 26 December 1894 to the morning of 18 February. Ben Nevis lay close to the centre of an anticyclone on 20 February 1895 (Figure 8). Figure 9 shows the mean wind speed and calculated RH at each hourly observation over the period 18-20 February. Aside from more extensive cloud cover during the afternoon of 18 February, skies were cloudless or nearly so until 1200 GMT on 20 February, when the summit became enveloped in cloud for the remainder of the day. Winds were fresh south-easterly on 17th, falling light on 18th then backing north-east by evening before falling calm for long periods on 19 February, after which they picked up from the north-west or north during the afternoon of 19 February; by late evening mean winds were $6-8 \mathrm{~m} \mathrm{~s}^{-1}$, reaching $12 \mathrm{~m} \mathrm{~s}^{-1}$ by 0500 GMT on 20 February. The first observation of very low humidity occurred on 17 February, when at 1500 GMT 
the calculated RH stood at $18 \%$, the wind east-south-easterly at $7 \mathrm{~m} \mathrm{~s}^{-1}$; thereafter the RH remained at or below $25 \%$ for 63 consecutive hours. Calculated RH values become negative (using $A=1$ for winds below $2 \mathrm{~m} \mathrm{~s}^{-1}$ ) for all but one hour in 21 consecutive hours from 2100 GMT on 18 February, but as stated above such conclusions are suspect given the very light winds (eight hours during 19 February were 'flat calm', i.e. wind speed zero, without a wind direction). Assuming a slightly lower but feasible value of $A$, say 0.8 , gives RH values mostly in the range from 0 to $10 \%$, as indicated by the dotted grey RH line on Figure 9.

We can have more confidence in the calculated RH from 1800 GMT on 19 February, because winds freshened once more from the north-north-west (and thus we can infer that screen ventilation improved). Typical RH values were 5-15\% until $0500 \mathrm{GMT}$, with winds increasing to 6-12 $\mathrm{m} \mathrm{s}^{-1}$. At 0100 GMT on 20 February, with the dry-bulb at $-0.9^{\circ} \mathrm{C}$ and the wet-bulb (ice-bulb) at $-6.6{ }^{\circ} \mathrm{C}$, the wind north-west averaging about $8 \mathrm{~m} \mathrm{~s}^{-1}$, the calculated $\mathrm{RH}$ fell to $0.5 \%$. Conditions were almost unchanged the following hour, when the calculated $\mathrm{RH}$ was $2 \%$. The values recorded on this date and on 10 September 1894 are probably as close to zero as can be expected, given the limitations of thermometry at such low levels of water vapour content, and remain amongst the lowest reliably recorded RH values on record within the British Isles.

The notes from the Observatory logbook for this event read as follows:

Feb. 17. - Not a particle of cloud seen to-day either above or below summit. Aurora seen till $5 \mathrm{~h}$ and after 20h. At the latter hour the zodiacal light was seen. Air exceedingly dry to-day, humidity being below $20 \%$ at $1 \mathrm{~h}$ and $3 \mathrm{~h}$ and from $15 \mathrm{~h}$ till midnight.

Feb. 18. - The south-easterly wind that has been blowing since the morning of 13th died out this afternoon. Aurora seen in morning and again at night and the zodiacal light at 20h. Air very dry again today, the maximum humidity being only $28 \%$. Today the temperature rose to the freezing point for the first time since 25th Dec.

Feb. 19. - Cloudless, and air very dry all day. Aurora seen in morning and at night, and the zodiacal light at $20 \mathrm{~h}$.

Feb. 20. - Cloudless and air very dry till 1h. Fog for the rest of the day. Aurora seen at $1 \mathrm{~h}$ and $2 h$.

EXAMPLE 3: 30 JANUARY TO 2 FEBRUARY 1902

Towards the end of January 1902, barometric pressure rose rapidly in the lee of a deep depression that crossed Scotland on 28 January, and an intense anticyclone became established over the Baltic and Scandinavia with a strong ridge westwards towards Scotland during 31 January-1 February. The synoptic situation at 1200 GMT on 1 February is shown in Figure 10. This occasion is doubly noteworthy, as the anticyclone in question produced the highest mean sea level barometric pressure yet observed in the British Isles - at 2200 GMT on 31 January the pressure stood at $1053.6 \mathrm{hPa}$ at Aberdeen and 1053.4 hPa at Fort William (Burt 2007). Occasional examples of low RH are evident in the Ben Nevis Observatory record from 30 January, but the main spell of dry air occurred during 1 February (Figure 11), when the calculated RH remained below $20 \%$ for 17 consecutive hours from 0300 GMT on 1 February. The sky was largely free of cloud during this event; the winds were northerly at the beginning of the spell, veering south-easterly during 30 January and remaining southeasterly or east-south-easterly throughout 31 January and 1 February, before backing north-easterly on 2 February. Except for a few hours late on 30 January winds were brisk throughout, and during the period of lowest RH on 1 February averaged $12 \mathrm{~m} \mathrm{~s}^{-1}$. In the 13 hours commencing 0600 GMT, only one hour exceeded $10 \% \mathrm{RH}$, the lowest being $2 \%$ at $1300 \mathrm{GMT}$ (dry-bulb $1.2{ }^{\circ} \mathrm{C}$, wet/ice-bulb -5.0 ${ }^{\circ} \mathrm{C}$, wind north-easterly averaging $8 \mathrm{~m} \mathrm{~s}^{-1}$ ), and $3 \%$ at 1800 GMT. This event was written up in the logbook as follows: 
Jan. 30. - Air exceptionally dry and clear after 4 h, the lowest humidity being 14 per cent. at 2lh. Sky cloudless all day, except for a little cirrus moving slowly from N. A little fog on hills to E and SE in early morning and over Locheil during the day. The cirrus seen at $5 \mathrm{~h}$ was ribbed, resembling the shape of an opened fan, the apex being about $7^{\circ}$ above the southern horizon, and the rays extending to the zenith.

Jan. 31. - Pressure high all day. The reading at 23h, viz. 26.258 inches [889.2 hPa], is the highest recorded at this Observatory, being 0.003 higher [0.1 hPa] than that in January 1896. The air has been exceptionally dry all day, the lowest humidity being 11 per cent. at $17 \mathrm{~h}$, and the mean for the day 22 per cent. Sky cloudless and air very clear all day. A little fog in valley to SE in early morning and over Locheil and Loch Lochy during the day.

Feb. 1. - Air dry, the humidity ranging from 12 to 53 per cent., and sky cloudless down to horizon all day.

Feb. 2. - Air very dry all day, the mean humidity being 39 per cent. A little cirrus on sky in forenoon, but clearing away in the afternoon. Fog below all round most of the day, on which glories were seen in afternoon.

\section{DISCUSSION AND CAUSES}

All of the examples listed in the previous section share a common synoptic feature - a nearby anticyclone (corroborated by the mean station-level pressure of the ' $5 \% \mathrm{RH}$ events' being $14 \mathrm{hPa}$ above normal). Such instances of dry air at the summit of Ben Nevis are textbook examples of the warming and drying effects of anticyclonic subsidence. Air gently subsides within anticyclones, and as air subsides it warms through compression at or close to the dry adiabatic lapse rate, $10 \mathrm{degC}$ per $1000 \mathrm{~m}$ in the lower troposphere. Air descending from considerable heights in the troposphere will be very cold and will contain very little water vapour by virtue of its low temperature. As the air descends and warms, within a large anticyclone it will gain little if any additional moisture until it intercepts the planetary boundary layer, at which point a stable subsidence inversion forms to mark the boundary between moister planetary boundary layer and the warmer, drier subsided air.

Such anticyclonic subsidence inversions are familiar features on upper-air diagrams such as tephigrams or skew-T plots. Figure 12 shows the sounding from Camborne in south-west England for 1200 UTC on 21 March 2018, when a large anticyclone (1038 hPa) lay to the south-west of the British Isles. A pronounced subsidence inversion is present at $883 \mathrm{hPa}$, the RH decreasing from 100\% at $884 \mathrm{hPa}$ (1266 m AMSL) to $9 \%$ at $881 \mathrm{hPa}$ (1292 m AMSL) - less than 30 metres in altitude separating saturated air from very dry air. On this occasion, had this been a sounding near Ben Nevis, only the topmost reaches of the mountain (summit observatory at $1345 \mathrm{~m}$ ) would be located within the very dry air, with a sudden fall in RH heralding the 'descent' of the subsidence inversion.

Very rapid rises or falls and/or periods of very rapid fluctuations in RH are often symptomatic of the descent of such subsidence inversions over British mountains, as the Ben Nevis Observatory examples in Figures 7,9 and 11 clearly show. A recent example occurred on Great Dun Fell in Cumbria (857 m AMSL) on 2-3 March 2011 (Burt 2011), where the 1 minute record of a capacitance RH sensor revealed very rapid RH fluctuations between 15 and 70\% RH over a 2-3 hour period as the subsidence inversion 'settled' over the summit; the RH eventually fell to $5.6 \%$. More recently, the Aonach Mòr site recorded 0\% RH at 0900 and 1100 UTC on 10 June 2015, and the Cairngorm Summit site logged similar values at 0600 GMT on 5 June 2018 and again at 0500 and 0600 GMT on 6 June 2018. Very dry air at summit level on both occasions is supported by Scottish upper-air ascent data. Clearly, the newly-digitised nineteenth-century observations of near-zero humidity on the summits of the highest Scottish mountains, whilst rare, are fully borne out by modern records. 


\section{Summary and conclusions}

Although the occurrence of spells of such extremely dry air on this notoriously wet mountain summit in western Scotland puzzled contemporary meteorologists, the cause and dynamics of anticyclonic subsidence are well-understood today. Recent digital access to the hourly observation records from the Ben Nevis Observatory, together with improved insights into the parameters used in the psychrometric equation, has allowed the examination of the circumstances surrounding these episodes of near-zero RH to be conducted in greater detail, and with improved confidence in the reliability of the derived humidity values, than previously possible. It is likely that, within the limitations of the thermometry in use at the Ben Nevis Observatory and the assumptions necessarily involved within the psychrometric calculations, on occasions the water vapour content of the air on the summit of this mountain in western Scotland fell as close to zero as could be realistically measured with standard meteorological instruments of the era. The occurrence and frequency of such events are fully supported by contemporary measurements made on two other Scottish mountain summits.

\section{Acknowledgements}

This project would not have been possible without the tireless efforts of the thousands of volunteers who donated their spare time to help rescue this unique dataset. Marjory Roy provided invaluable assistance in helping get the project off the ground and in tracking down Ben Nevis records and references. Philip Brohan (UK Met Office) kindly contributed reanalysis plots, including $850 \mathrm{hPa}$ humidity ensembles. Data from Cairngorm and Aonach Mòr was kindly provided by Mark McCarthy from the Met Office's National Climate Information Centre under an Open Government License and is now available online (Met Office, 2019 \{, \#1457@@ @idden\}). The UK Natural Environment Research Council (NERC) provided funding through their Public Engagement programme and the National Centre for Atmospheric Science (NCAS) also supported the project. EH received funding from a NERC Advanced Fellowship (grant NE/I020792/1). The authors remain grateful to two anonymous referees who provided numerous useful comments and suggestions on an early version of this paper.

\section{Dataset access}

The full Ben Nevis digitised dataset is now available at Geoscience Data Journal (Hawkins et al 2019). The hourly dry-bulb, wet-bulb, pressure, wind speed and direction and calculated RH dataset is available, with documentation, at xxx tbc.

\section{REFERENCES}

Barton, J. S., 1984: Observing mountain weather using an automatic station. Weather, 39, 140-145. Bolton, D., 1980: The computation of equivalent potential temperature. Mon. Weather Rev., 108, 1046-1053.

Buchan, A., 1890: Meteorology of Ben Nevis. Trans. Roy. Soc. Edinb., 34, xvii-lxi.

Buchan, A., and R. T. Omond, 1902: The Ben Nevis observations (1888-1892). Trans. Roy. Soc.

Edinb., 42.

1905: The Ben Nevis observations (1893-1897). Trans. Roy. Soc. Edinb., 43.

Burt, S., 2007: The Highest of the Highs ... Extremes of barometric pressure in the British Isles, Part 2 - the most intense anticyclones. Weather, 62, 31-41.

- 2011: Exceptionally low relative humidity in northern England, 2-3 March 2011. Weather, 66, 197-199.

—_, 2012: The Weather Observer's Handbook. Cambridge University Press, 444 pp. pp.

Curran, J. C., G. E. Peckham, D. Smith, A. S. Thom, J. S. G. McCulloch, and I. C. Strangeways, 1977: Cairngorm summit automatic weather station. Weather, 32, 61-63.

Dickson, H. N., 1885: The hygrometry of Ben Nevis. Proceedings of the Royal Society of Edinburgh, xiii, 950-960.

Duncan, C. N., and K. J. Weston, 1983: Ben Nevis observatory, 1883-1983. Weather, 38, 298-303. 
Glaisher, J., 1869: Hygrometrical Tables (Fifth Edition). Taylor and Francis, London.

Green, F. H. W., 1953: A remarkable low humidity. Weather, 8, 182-184.

— 1965: The incidence of low relative humidity in the British Isles. Meteorol. Mag., 94, 84-88.

1966: Low air humidities 28 March to 2 April 1965. Weather, 21, 101-104.

1967: Air humidity on Ben Nevis. Weather, 22, 174-186.

Harrison, R. G., 2014: Meteorological measurements and instrumentation. Wiley.

Harrison, R. G., and C. R. Wood, 2012: Ventilation effects on humidity measurements in thermometer screens. Quart. J. Royal Meteorol. Soc., 138, 1114-1120.

Hawkins, E., S. Burt, S. Thomas, M. Lockwood, P. Brohan, H. Richardson, and M. Roy, 2019:

Hourly weather observations from the Scottish Highlands (1883-1904) rescued by volunteer citizen scientists. (Shortly to be submitted to Geoscience Data Journal; citation to be updated at proof) Herbertson, A. J., 1905: Comparison of dry and wet-bulb records in Stevenson screen and aspirationpsychrometer under different weather conditions. Trans. Roy. Soc. Edinb., 43, 529-564.

Kendon, M., and M. Diggins, 2019: Severe weather and snow conditions on Cairngorm summit in February to March 2018. Weather, online doi:10.1002/wea.3390 [accessed 22 February 2019]

McConnell, D., 1988a: The Ben Nevis Observatory logbooks, Part 1. Weather, 43, 356-362.

— 1988b: The Ben Nevis Observatory logbooks, Part 2. Weather, 43, 396-401.

Met Office, 2019: Met Office MIDAS Open: UK Land Surface Stations Data (1853-current). Centre for Environmental Data Analysis, accessed 22 February 2019.

http://catalogue.ceda.ac.uk/uuid/dbd451271eb04662beade68da43546e1

Omond, R. T., 1910: The meteorology of the Ben Nevis observatories Part IV, containing the observations for the years 1898-1904. Vol. 46, Part I.

Roy, M., 2004: The weathermen of Ben Nevis 1883-1904. Royal Meteorological Society, 62 pp. Townsend, C. F., 1967: Air humidity on Ben Nevis (Letter to the Editor). Weather, 22, 473-474. World Meteorological Organization (WMO), 2014: WMO No.8 - Guide to Meteorological Instruments and Methods of Observation (CIMO guide) (Updated version, May 2017), 1139 pp. 
Table 1. Variation of psychrometric coefficient $A$ used in relative humidity calculations with observed Ben Nevis Observatory wind speed

\begin{tabular}{lll} 
Ben Nevis Force & Nominal speed in $\mathrm{m} \mathrm{s}^{-1}$ & $\begin{array}{l}\text { Assigned } \\
\text { value of } A\end{array}$ \\
\hline 0, Calm (no wind direction) & 0 & 1.0 \\
0, wind direction given & 0.25 & 1.0 \\
1 & 3 & 0.7 \\
2 & 6 & 0.7 \\
Range $0-1$ & Average of Force 0 and 1, i.e. $1.5 \mathrm{~m} \mathrm{~s}^{-1}$ & 1.0 \\
Range $0-2$ & Average of Force 0 and 2, i.e. $3 \mathrm{~m} \mathrm{~s}^{-1}$ & 0.7 \\
3 and above & $\geq 10$ & 0.7
\end{tabular}

Table 2. Frequencies of RH within 5\% bins at the Ben Nevis Observatory, April 1884 to September 1904. RH calculated using modern psychrometric methods as described in the text, and constrained within 0 and $100 \%$ RH. All observations of $10 \%$ RH or less have a wind speed value associated with them; for other records between 1883 and 1892 inclusive, where hourly wind speeds are not available, the Ben Nevis Observatory mean wind speed of approx $7 \mathrm{~m} \mathrm{~s}^{-1}$ has been assumed in the calculation

\begin{tabular}{lccccc}
$R H, \%$ & Frequency & $\begin{array}{c}\text { Per mille } \\
\text { frequency }\end{array}$ & $R H, \%$ & Frequency & $\begin{array}{c}\text { Per mille } \\
\text { frequency }\end{array}$ \\
\hline $0-5$ & 223 & 1.2 & $50-55$ & 1292 & 7.1 \\
$5-10$ & 145 & 0.8 & $55-60$ & 1663 & 9.2 \\
$10-15$ & 287 & 1.6 & $60-65$ & 1996 & 11 \\
$15-20$ & 395 & 2.2 & $65-70$ & 2302 & 13 \\
$20-25$ & 461 & 2.5 & $70-75$ & 2675 & 15 \\
$25-30$ & 539 & 3.0 & $75-80$ & 3390 & 19 \\
$30-35$ & 666 & 3.7 & $80-85$ & 3839 & 21 \\
$35-40$ & 825 & 4.5 & $85-90$ & 4884 & 27 \\
$40-45$ & 977 & 5.4 & $90-95$ & 6565 & 36 \\
$45-50$ & 1156 & 6.4 & $95-100$ & 147236 & 811 \\
& & & Total all obs & 181516 & 1000
\end{tabular}

Table 3. Location and record details of contemporary high-altitude AWS sites used for comparison with historical Ben Nevis humidity data

\begin{tabular}{lccc} 
& \multicolumn{1}{c}{ Ben Nevis } & \\
& Observatory & Aonach Mòr & Cairngorm Summit \\
\cline { 2 - 4 } Latitude $\left({ }^{\circ} \mathrm{N}\right)$ & 56.80 & 56.82 & 57.12 \\
Longitude $\left({ }^{\circ} \mathrm{W}\right)$ & 5.00 & 4.97 & 3.64 \\
Altitude (m AMSL) & 1345 & 1130 & 1237 \\
Distance from Ben Nevis summit & - & $3.5 \mathrm{~km} \mathrm{NE}$ & $91 \mathrm{~km}$ ENE \\
Record period (within) & $12 / 1883$ to $9 / 1904$ & $2 / 1992$ to $12 / 2018$ & $12 / 1991$ to $12 / 2018$ \\
No of observations & 182616 & 197113 & 222469 \\
\% availability & 100.0 & 83.3 & 90.6 \\
No of humidity observations & 181518 & 178365 & 176910 \\
\% observations with humidity data & 99.4 & 90.5 & 79.5 \\
Mean RH, \% (all valid observations) & 94.4 & 90.4 & 88.9
\end{tabular}

The Met Office currently operate a network of six mountain stations in the UK, including Aonach Mòr and Cairngorm Summit. A recent paper by Kendon and Diggins (2019) provides a brief overview of the technology providing records from these very challenging environments. Data for Aonach Mòr and Cairngorm Summit (and the other four UK mountain sites) are now also available online (Met Office 2019) 
Table 4. All dates when at least one valid hourly observation had a calculated RH 5 per cent or lower, Ben Nevis Observatory December 1883 to September 1904 (see text for calculation method). All values converted from original units. Observed station level pressures (not shown) used in the calculation. Minimum hourly RH shown as $<0$ indicates that a negative RH resulted from the calculation and the value was constrained to 0 . Mean dry-bulb temperatures and mean wind speeds are also given for the spells listed, and maximum and minimum temperatures where more than a single hour. Multiple hour spells may not all be contiguous within the given date. Dates in bold are examined in more detail in the text.

\begin{tabular}{|c|c|c|c|c|c|c|c|}
\hline Year & Date & $\begin{array}{c}\text { Hours } \\
R H \leq \\
5 \%\end{array}$ & $\begin{array}{r}\text { Minimum } \\
\text { calculated } \\
\text { hourly RH\% }\end{array}$ & $\begin{array}{r}\text { Mean spell } \\
\text { (dry-bulb) } \\
\text { temperature } \\
{ }^{\circ} \mathrm{C}\end{array}$ & $\begin{array}{r}\text { Maximum } \\
\text { spell } \\
\text { temperature } \\
{ }^{\circ} \mathrm{C}\end{array}$ & $\begin{array}{r}\text { Minimum } \\
\text { spell } \\
\text { temperature } \\
{ }^{\circ} \mathrm{C}\end{array}$ & $\begin{array}{c}\text { Mean } \\
\text { spell } \\
\text { wind } \\
\text { speed } \\
m^{-1}\end{array}$ \\
\hline 1886 & 12 March & 3 & $<0$ & -6.3 & -5.7 & -7.1 & $<1$ \\
\hline \multirow[t]{2}{*}{1888} & 15 January & 2 & 2 & 2.2 & & & 1 \\
\hline & 22 October & 1 & 4 & 6.4 & & & 6 \\
\hline 1889 & 27 March & 2 & $<0$ & -1.4 & -0.7 & -2.1 & 3 \\
\hline 1890 & 25 February & 2 & $<0$ & 7.2 & 7.2 & 7.2 & 2 \\
\hline \multirow[t]{3}{*}{1892} & 24 December & 1 & 0 & -2.7 & & & 12 \\
\hline & 25 December & 15 & $<0$ & -1.9 & 0.1 & -2.7 & 2 \\
\hline & 26 December & 6 & $<0$ & -1.8 & -1.2 & -2.2 & 1 \\
\hline \multirow[t]{2}{*}{1893} & 29 August & 1 & $<0$ & 8.4 & & & 1 \\
\hline & 3 September & 1 & 4 & 10.9 & & & 1 \\
\hline \multirow[t]{6}{*}{1894} & 14 February & 2 & $<0$ & -6.8 & -6.4 & -7.1 & $<1$ \\
\hline & 10 September & 8 & 0 & 9.5 & 9.9 & 9.2 & 10 \\
\hline & 16 September & 1 & 2 & 9.6 & & & 1 \\
\hline & 4 October & 14 & $<0$ & 10.9 & 13.1 & 8.9 & $<1$ \\
\hline & 5 October & 3 & $<0$ & 10.9 & 10.9 & 10.6 & 1 \\
\hline & 11 October & 2 & 4 & 5.6 & 5.6 & 5.6 & 8 \\
\hline \multirow[t]{4}{*}{1895} & 18 February & 5 & $<0$ & -0.1 & 0.6 & -0.9 & 1 \\
\hline & 19 February & 17 & $<0$ & 0.5 & 3.6 & -1.4 & $<1$ \\
\hline & 20 February & 2 & $<1$ & -0.8 & -0.6 & -0.9 & 8 \\
\hline & 25 November & 1 & $<0$ & 2.6 & & & 0 \\
\hline \multirow[t]{4}{*}{1896} & 9 January & 4 & $<0$ & -1.1 & -0.4 & -1.7 & $<1$ \\
\hline & 3 November & 1 & 2 & -2.4 & & & 0 \\
\hline & 26 November & 1 & 3 & 3.2 & & & 0 \\
\hline & 27 November & 3 & $<0$ & 3.3 & 3.9 & 2.3 & $<1$ \\
\hline \multirow[t]{9}{*}{1897} & 12 February & 4 & $<0$ & -1.7 & -1.0 & -3.3 & 0 \\
\hline & 22 April & 1 & $<0$ & -1.0 & & & $<1$ \\
\hline & 24 April & 1 & 4 & -0.1 & & & 1 \\
\hline & 20 May & 1 & $<0$ & 3.5 & & & 1 \\
\hline & 23 May & 3 & $<0$ & -2.0 & -1.8 & -2.2 & $<1$ \\
\hline & 4 November & 4 & $<0$ & 9.9 & 11.1 & 7.8 & 1 \\
\hline & 5 November & 2 & 2 & 5.5 & 6.3 & 4.7 & $<1$ \\
\hline & 18 December & 5 & $<0$ & 0.5 & 1.0 & -0.2 & $<1$ \\
\hline & 19 December & 4 & $<0$ & 1.1 & 1.8 & 0.5 & $<1$ \\
\hline \multirow[t]{6}{*}{1898} & 28 June & 2 & 0 & 6.9 & 8.0 & 5.7 & $<1$ \\
\hline & 22 September & 5 & $<0$ & 5.7 & 6.1 & 5.1 & $<1$ \\
\hline & 23 September & 3 & $<0$ & 5.8 & 7.1 & 5.1 & $<1$ \\
\hline & 24 September & 8 & $<0$ & 8.8 & 11.7 & 6.5 & 0 \\
\hline & 25 September & 12 & $<0$ & 7.7 & 10.6 & 5.6 & 0 \\
\hline & 26 September & 6 & $<0$ & 6.0 & 8.1 & 5.4 & $<1$ \\
\hline \multirow[t]{5}{*}{1899} & 28 January & 3 & $<0$ & -0.7 & -0.3 & -1.1 & 0 \\
\hline & 19 February & 3 & $<0$ & -1.4 & -1.0 & -2.2 & 0 \\
\hline & 20 February & 1 & $<0$ & -1.1 & & & 1 \\
\hline & 11 May & 1 & 1 & 5.7 & & & 1 \\
\hline & 12 May & 1 & 5 & 4.7 & & & 0 \\
\hline \multirow[t]{6}{*}{1900} & 4 March & 1 & $<0$ & 1.3 & & & 1 \\
\hline & 5 March & 7 & $<0$ & 1.2 & 2.1 & 0.6 & $<1$ \\
\hline & 6 March & 3 & $<0$ & 1.3 & 2.5 & 0.6 & $<1$ \\
\hline & 7 March & 1 & 4 & 0.4 & & & 10 \\
\hline & 13 September & 1 & 5 & 13.9 & & & 1 \\
\hline & 18 November & 1 & 3 & 1.9 & & & 0 \\
\hline 1901 & 6 June & 1 & 4 & 5.6 & & & 1 \\
\hline
\end{tabular}




\begin{tabular}{|c|c|c|c|c|c|c|c|}
\hline \multirow[b]{2}{*}{1902} & 20 August & 7 & $<0$ & 10.8 & 12.5 & 9.6 & $<1$ \\
\hline & 30 January & 1 & 3 & -4.9 & & & 1 \\
\hline & 1 February & 8 & 2 & 1.1 & 1.9 & -0.3 & 10 \\
\hline \multirow{5}{*}{1904} & 16 March & 2 & $<0$ & 0.9 & 1.0 & 0.7 & $<1$ \\
\hline & 8 December & 5 & $<0$ & -2.9 & -2.6 & -3.3 & \\
\hline & 21 September & 2 & 1 & 7.9 & 8.1 & 7.7 & \\
\hline & 23 September & 8 & $<0$ & 6.9 & 8.8 & 6.0 & \\
\hline & 24 September & 7 & $<0$ & 5.4 & 6.9 & 5.0 & \\
\hline & Total hours & 223 & & & & & \\
\hline
\end{tabular}

Table 5. Frequency (number of hours) with $\mathrm{RH} \leq 5 \%$ at Ben Nevis Observatory December 1883 to September 1904 , by mean dry-bulb temperature and mean wind speed (for all the $\mathrm{RH} \leq 5 \%$ hours combined on any given date)

\begin{tabular}{llll}
$\begin{array}{l}\text { Dry-bulb } \\
\text { temperature, }{ }^{\circ} \mathrm{C}\end{array}$ & $\begin{array}{l}\text { Mean wind } \\
\text { speed } \leq 1 \mathrm{~m} \mathrm{~s}^{-1}\end{array}$ & $\begin{array}{l}\text { Mean wind speed } \\
\geq 2 \mathrm{~m} \mathrm{~s}^{-1}\end{array}$ & $\begin{array}{l}\text { Total } \\
\text { hours }\end{array}$ \\
\hline$\leq-5^{\circ} \mathrm{C}$ & 5 & 0 & 5 \\
-5 to $0{ }^{\circ} \mathrm{C}$ & 51 & 9 & 60 \\
0 to $5{ }^{\circ} \mathrm{C}$ & 48 & 9 & 57 \\
5 to $10^{\circ} \mathrm{C}$ & 63 & 12 & 75 \\
$\geq 10{ }^{\circ} \mathrm{C}$ & 26 & 0 & 26 \\
Total & 193 & 30 & 223
\end{tabular}

Table 6. Frequency (number of hours) with $\mathrm{RH} \leq 5 \%$ at Ben Nevis Observatory December 1883 to September 1904, by month. The greatest number of hours on any single date in each month is also given.

\begin{tabular}{|c|c|c|c|c|c|c|c|c|c|c|c|c|c|}
\hline & Jan & $\mathrm{Feb}$ & Mar & Apr & May & June & July & Aug & Sep & Oct & Nov & Dec & Total \\
\hline All & & & & & & & & & & & & & \\
\hline hours & 10 & 44 & 19 & 2 & 6 & 3 & 0 & 8 & 62 & 20 & 13 & 36 & 223 \\
\hline $\begin{array}{r}\text { Longest } \\
\text { duration } \\
\text { on one } \\
\text { date, }\end{array}$ & & & & & & & & & & & & & \\
\hline hours & 4 & 20 & 7 & 1 & 3 & 1 & 0 & 7 & 15 & 14 & 4 & 15 & 20 \\
\hline
\end{tabular}

Table 7. Frequency (number of hours) with $\mathrm{RH} \leq 5 \%$ at Ben Nevis Observatory December 1883 to September 1904 , by hour of day.

\begin{tabular}{cccc} 
Hour GMT & Frequency & Hour GMT & Frequency \\
\hline 01 & 8 & 13 & 7 \\
02 & 13 & 14 & 9 \\
03 & 9 & 15 & 6 \\
04 & 9 & 16 & 6 \\
05 & 12 & 17 & 9 \\
06 & 9 & 18 & 8 \\
07 & 9 & 19 & 6 \\
08 & 9 & 20 & 11 \\
09 & 10 & 21 & 12 \\
10 & 11 & 22 & 9 \\
11 & 13 & 23 & 11 \\
12 & 9 & 24 & 8 \\
& & Total & 223
\end{tabular}


Table 8. Minimum values of psychrometric coefficient $A$ to attain RH $0 \%$ or RH 5\% for those occasions when calculated RH fell below 0\%, for wind speeds below $2 \mathrm{~m} \mathrm{~s}^{-1}$ : Ben Nevis Observatory December 1883 to September 1904.

\begin{tabular}{lcc} 
Number of events & 124 & \\
\hline Mean & $R H=0 \%$ & $R H=5 \%$ \\
Median & 0.903 & 0.857 \\
SD & 0.908 & 0.863 \\
& 0.073 & 0.070 \\
Minimum value & & \\
Maximum value & 0.636 & 0.605 \\
Mean + 2 SD & 0.999 & 0.949 \\
Mean - 2 SD & 1.049 & 0.997 \\
& 0.755 & 0.718
\end{tabular}


Figure captions

Figure 1. Location of sites referred to in the text. Aonach Mòr is close to Ben Nevis and is not shown separately.

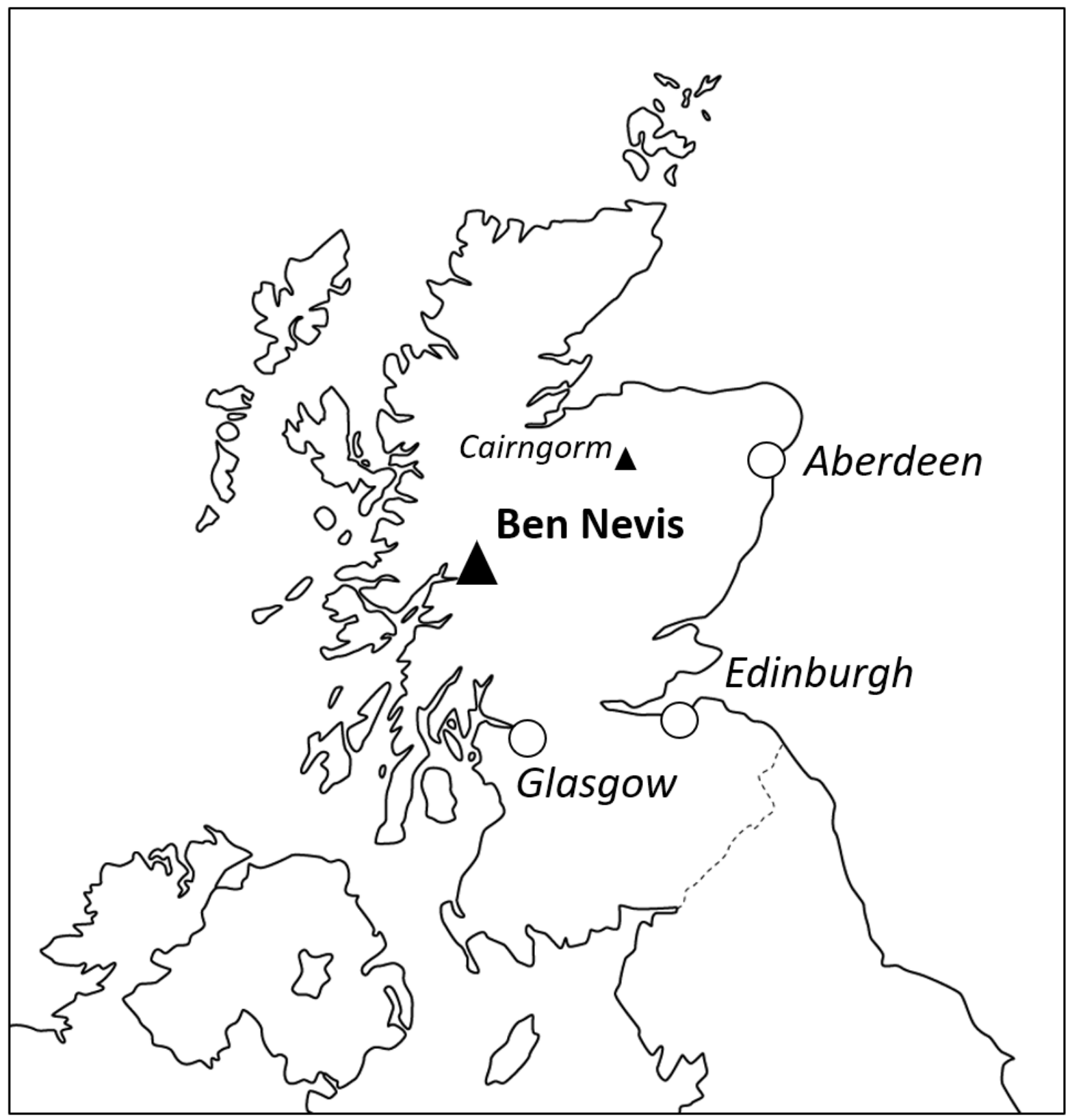


Figure 2. Ben Nevis Observatory from the south-west: contemporary photograph. These images are from the Royal Meteorological Society collection, held as part of the Met Office archive at National Records of Scotland, courtesy Royal Meteorological Society

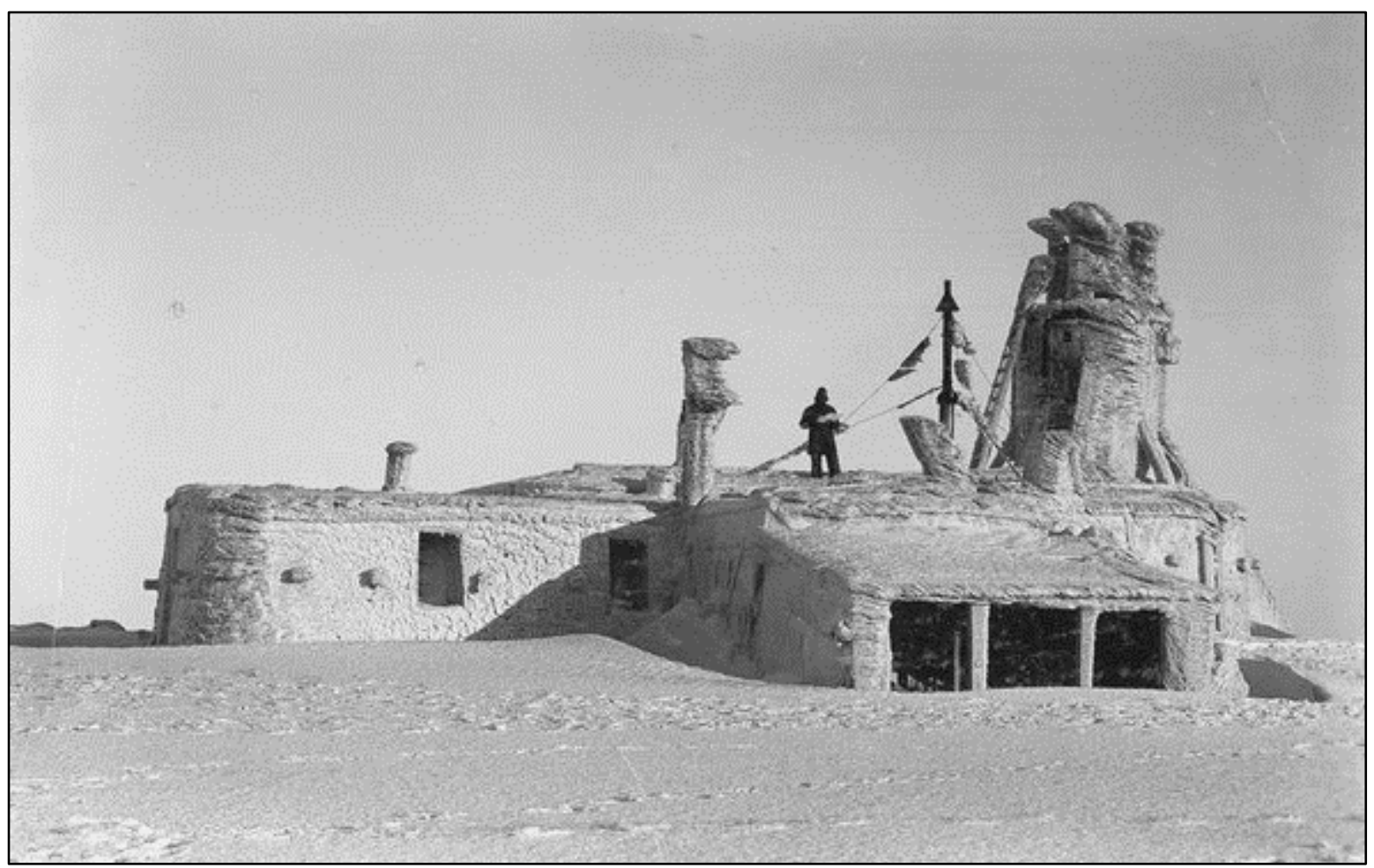

Figure 3. Ben Nevis Observatory from the south-east: contemporary photograph. These images are from the Royal Meteorological Society collection, held as part of the Met Office archive at National Records of Scotland, courtesy Royal Meteorological Society

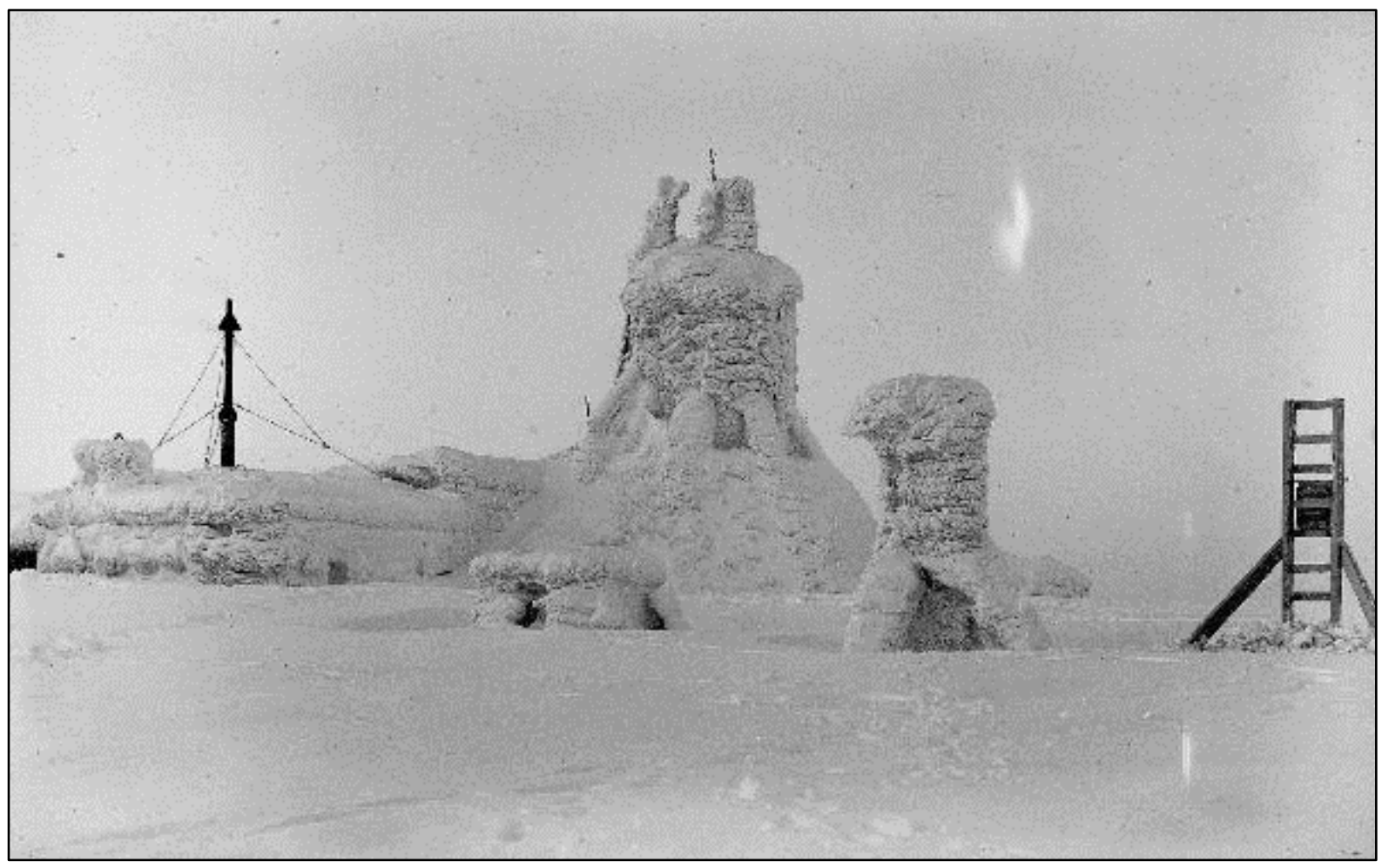


Figure 4. Dependence of psychrometer coefficient $A$ on ventilation speed. From Harrison and Wood, 2012, Figure 3.

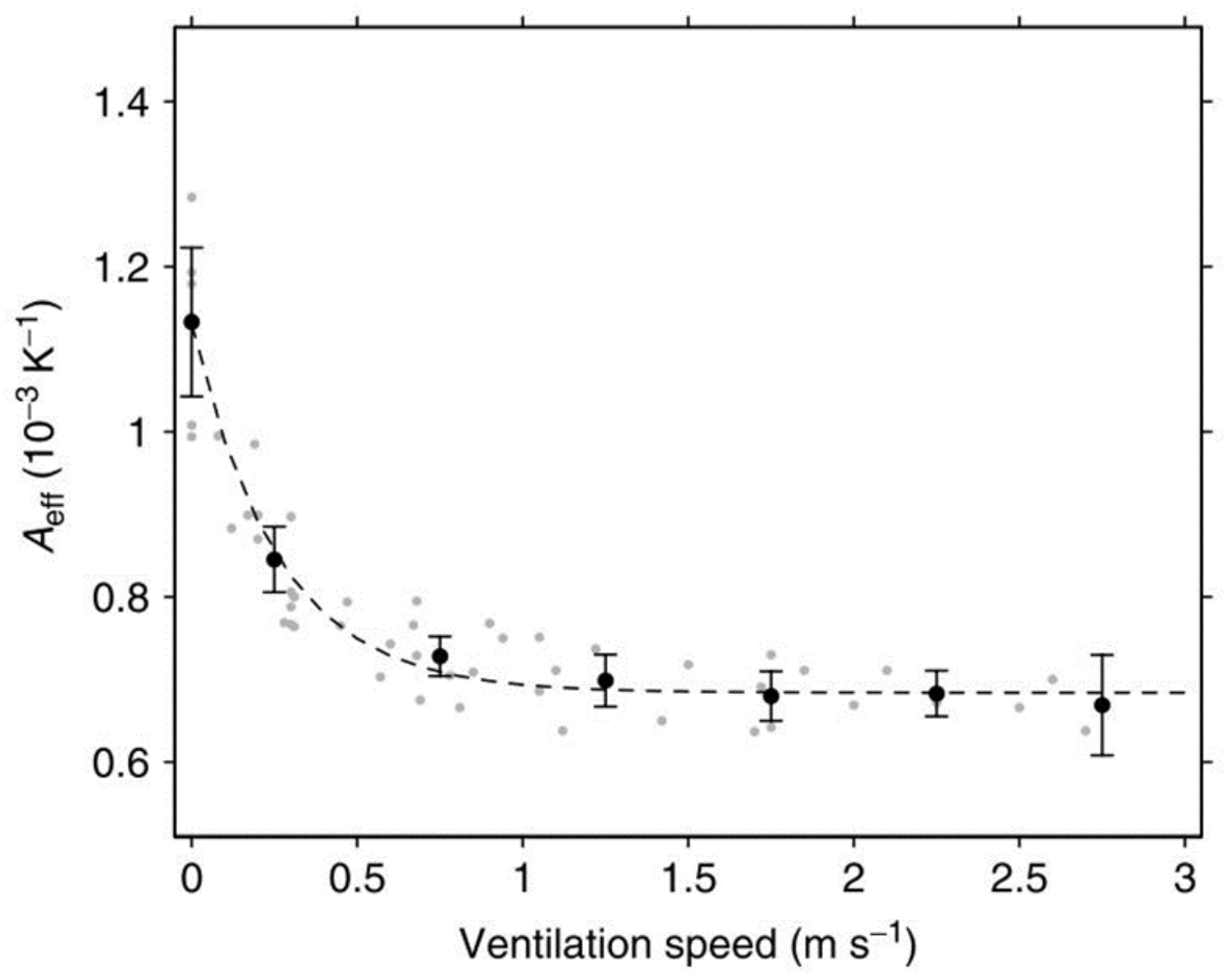


Figure 5. Frequency distribution of hourly relative humidity (per mille, log scale) at the Ben Nevis Observatory, Aonach Mòr and Cairngorm Summit, compared to a lowland site in southern England. Periods of record (20-25 years) and site details are given in Table 3. RH bins are 5\% RH ranges plotted to the upper bin limit.

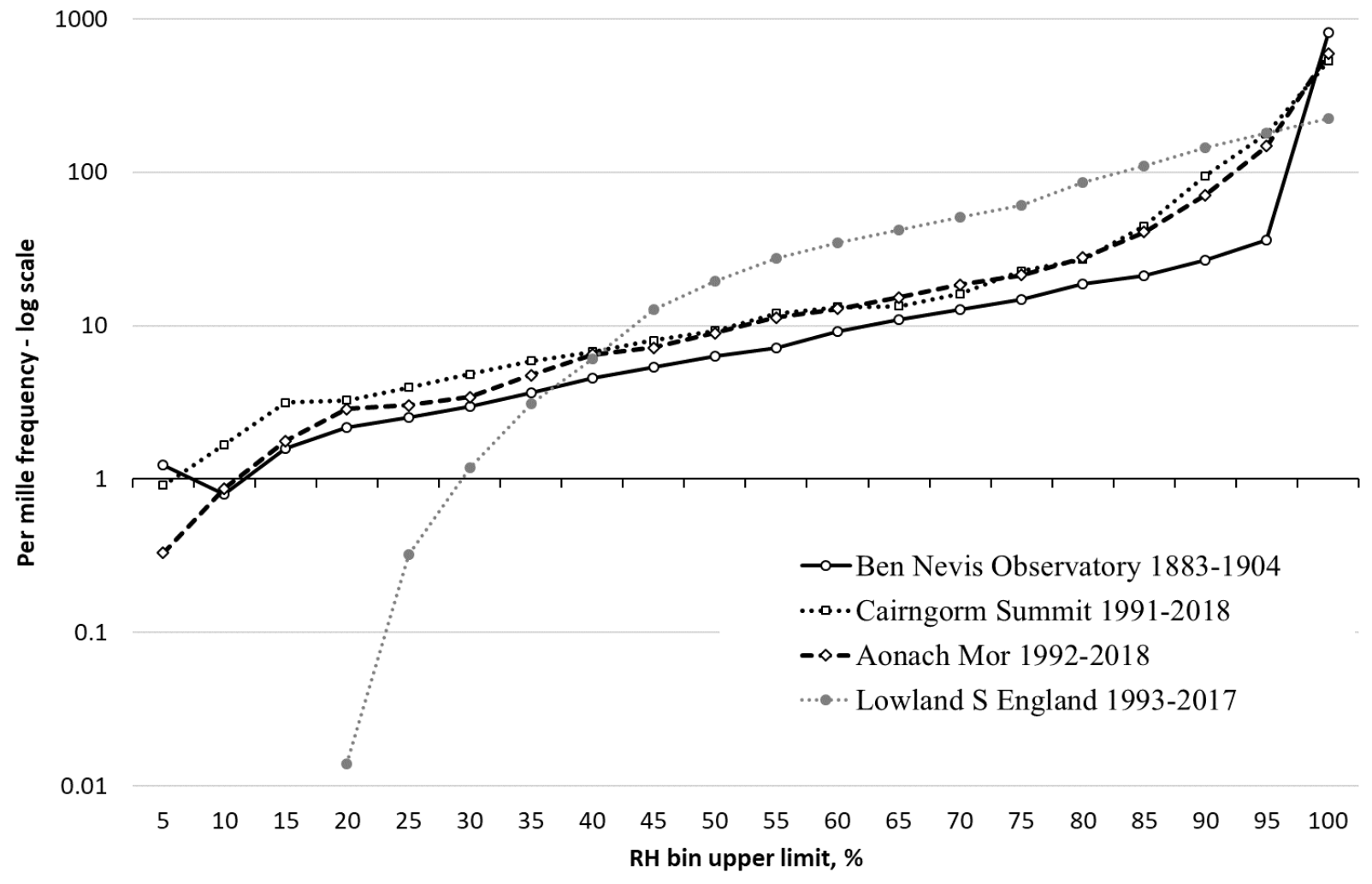


Figure 6. Synoptic situation at $1200 \mathrm{GMT}$ on 10 September 1894. Isobars are shown at $10 \mathrm{hPa}$ intervals from a reanalysis ensemble of multiple members; isobars with high location confidence are shown in black. Yellow dots mark the locations of sites whose pressure data was used to prepare this reanalysis product. The isobar enclosing most of the British Isles is $1030 \mathrm{hPa}$. Plot courtesy Philip Brohan, Met Office (Compo et al, 2011)

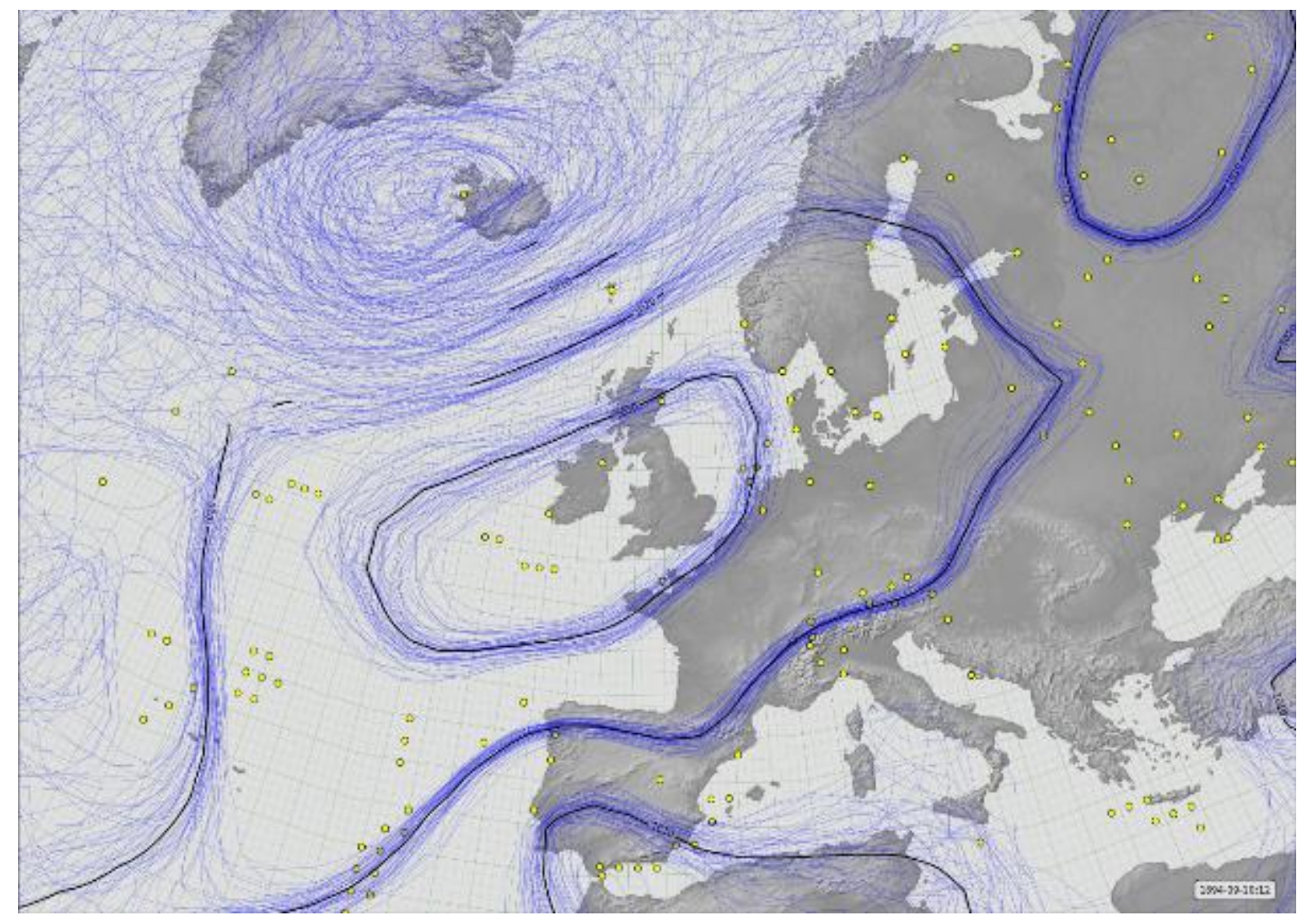


Figure 7. Time series of hourly wind speed ( $\mathrm{m} \mathrm{s}^{-1}$, grey columns) and calculated RH (\%, solid black line) over 9-10 September 1894 at the Ben Nevis Observatory, Scotland; dataset from Hawkins et al (2019). Time is in GMT. At 1600 GMT on 10 September 1894 the calculated RH was $0.1 \%$, surface wind north-westerly $14 \mathrm{~m} \mathrm{~s}^{-1}$.

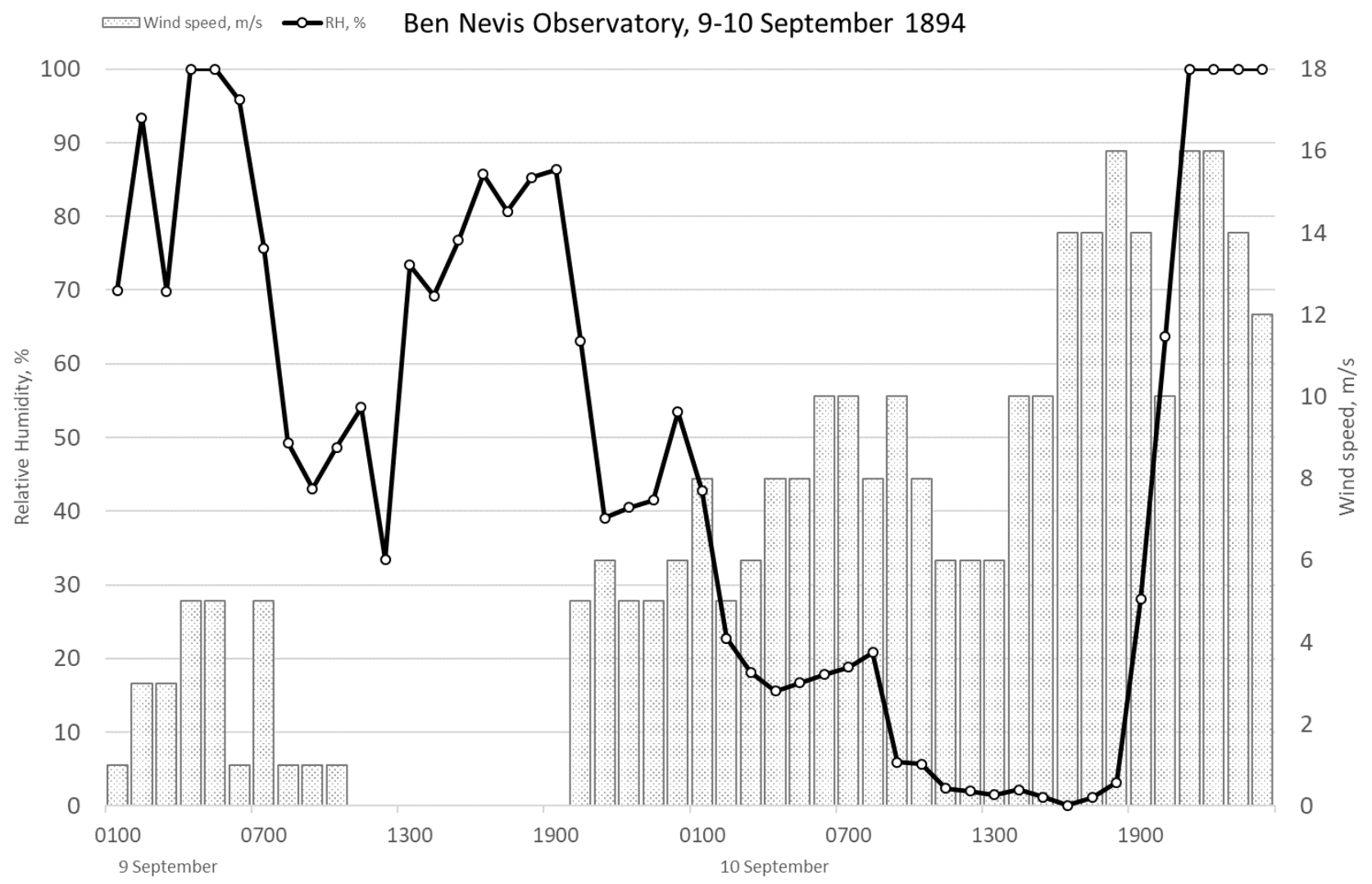


Figure 8. Synoptic situation at 1500 GMT on 19 February 1895. Legend as Fig. 7. Plot courtesy Philip Brohan, Met Office (Compo et al, 2011). The central isobar over Scotland is $1030 \mathrm{hPa}$.

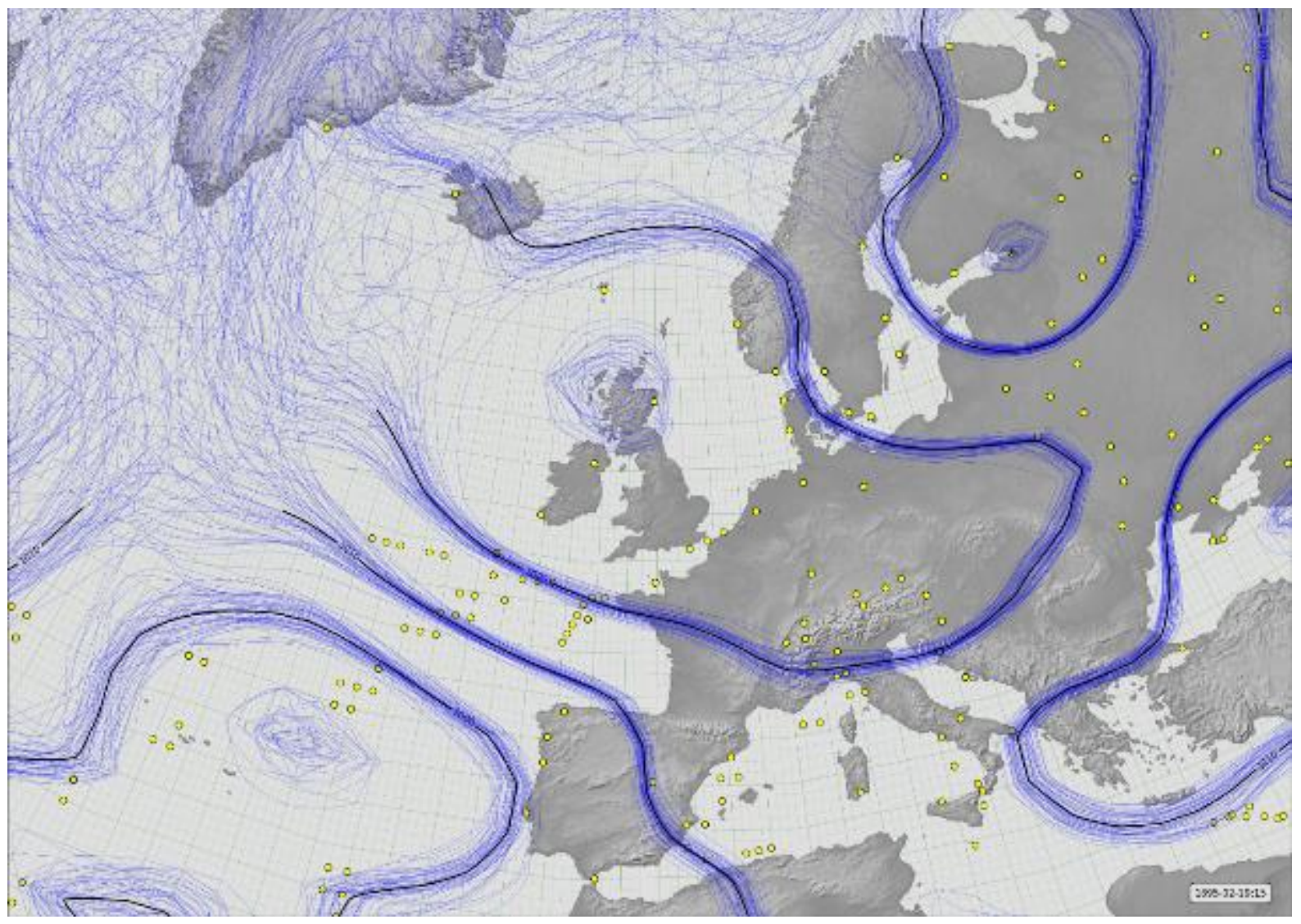


Figure 9. Time series of hourly wind speed ( $\mathrm{m} \mathrm{s}^{-1}$, grey columns) and calculated $\mathrm{RH}$ (\%, solid black line) over 18-20 February 1895 at the Ben Nevis Observatory, Scotland; dataset from Hawkins et al (2019). Time is in GMT. The dotted grey line shows RH values calculated assuming a psychrometric coefficient $A$ of 0.8 instead of 1.0 during light winds.

Ben Nevis Observatory, 18-20 February 1895

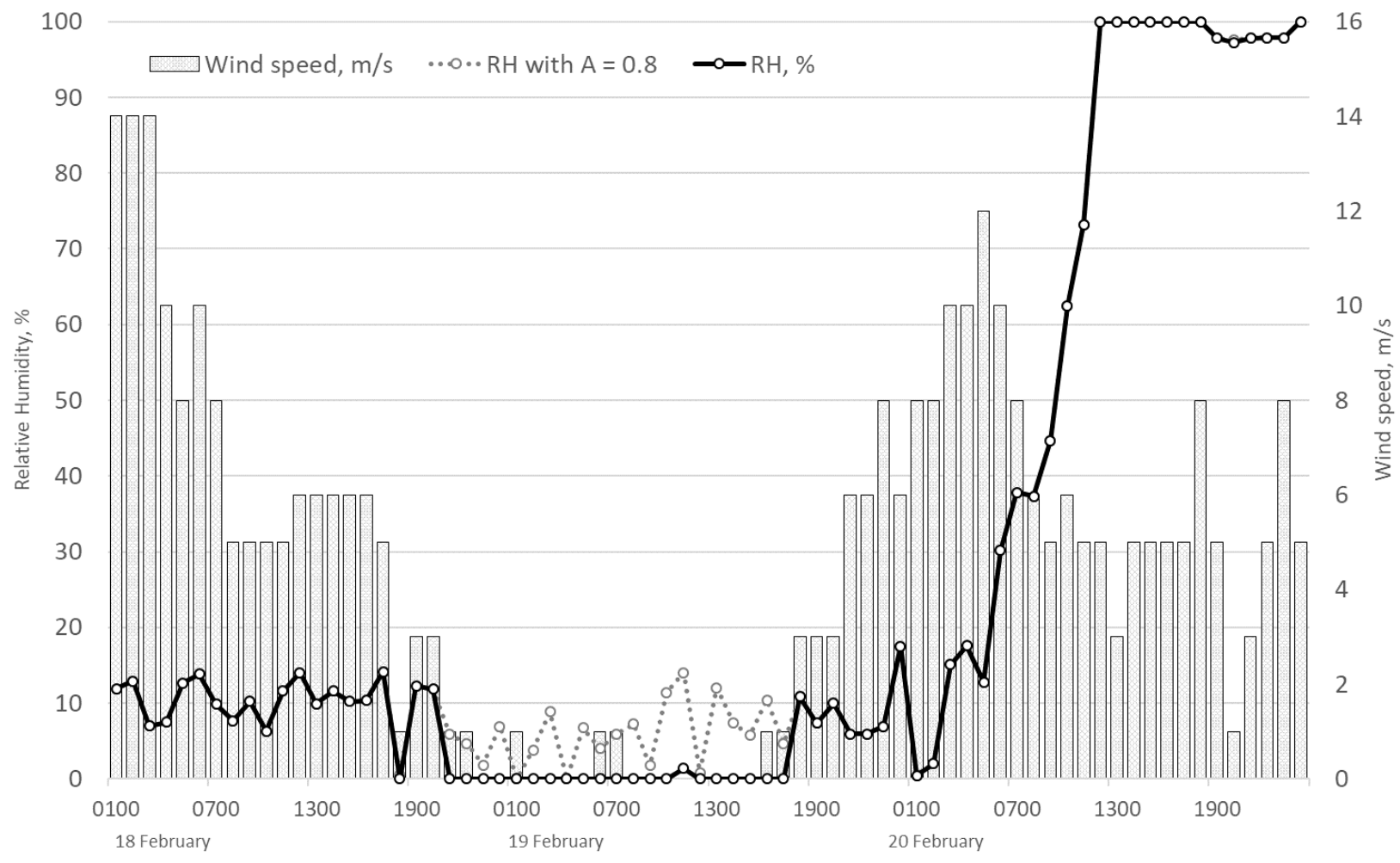


Figure 10. Synoptic situation at 1200 GMT on 1 February 1902. Legend as Fig. 7. Plot courtesy Philip Brohan, Met Office (Compo et al, 2011). The isobar enclosing Scotland is $1040 \mathrm{hPa}$. A second reanalysis plot for $850 \mathrm{hPa}$ (not shown) confirmed the existence of very dry air at this level.

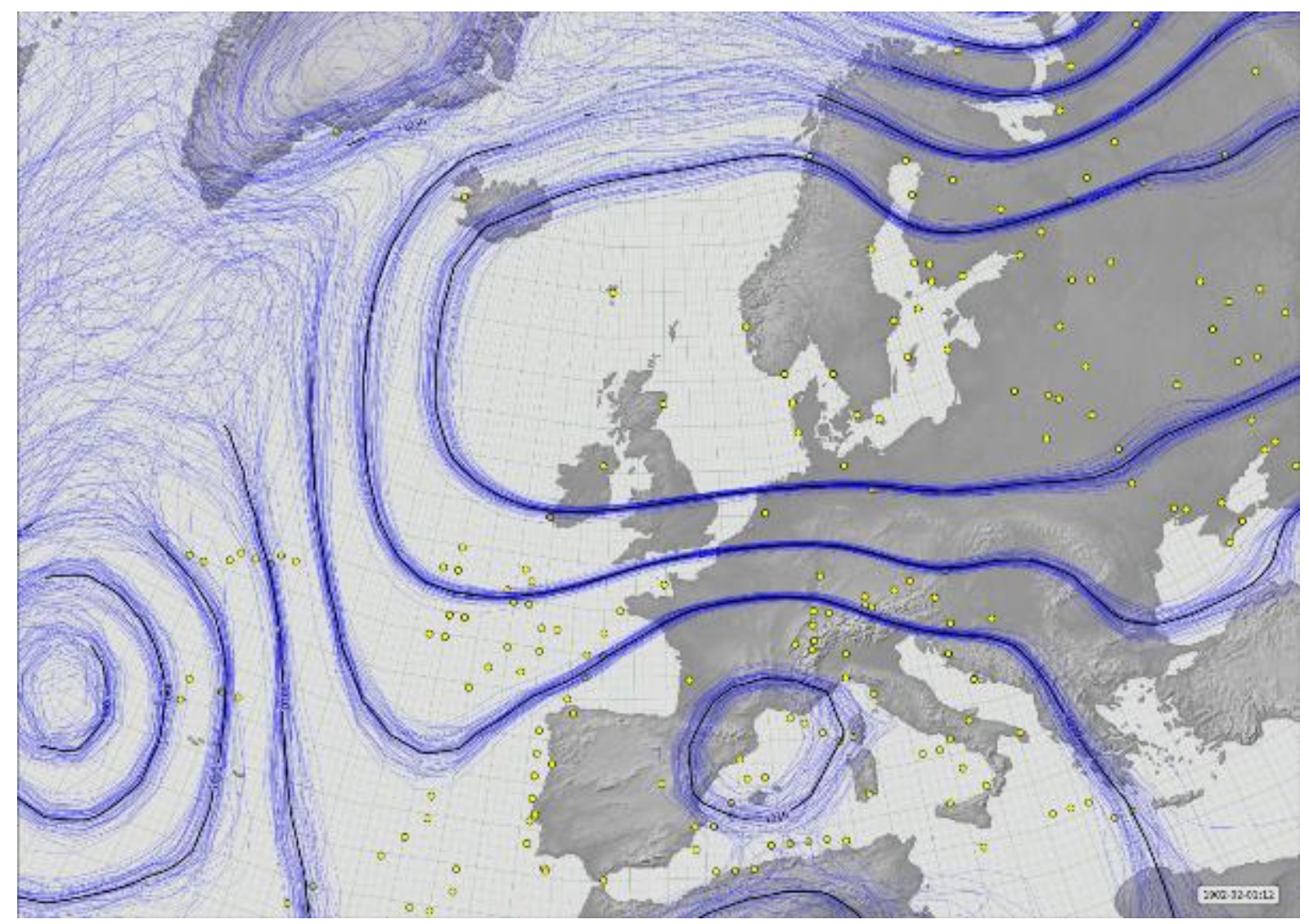


Figure 11. Time series of hourly wind speed ( $\mathrm{m} \mathrm{s}^{-1}$, grey columns) and calculated RH (\%, solid black line) over 30 January to 1 February 1902 at the Ben Nevis Observatory, Scotland; dataset from Hawkins et al (2019). Time is in GMT.

Ben Nevis Observatory, 30 January-1 February 1902

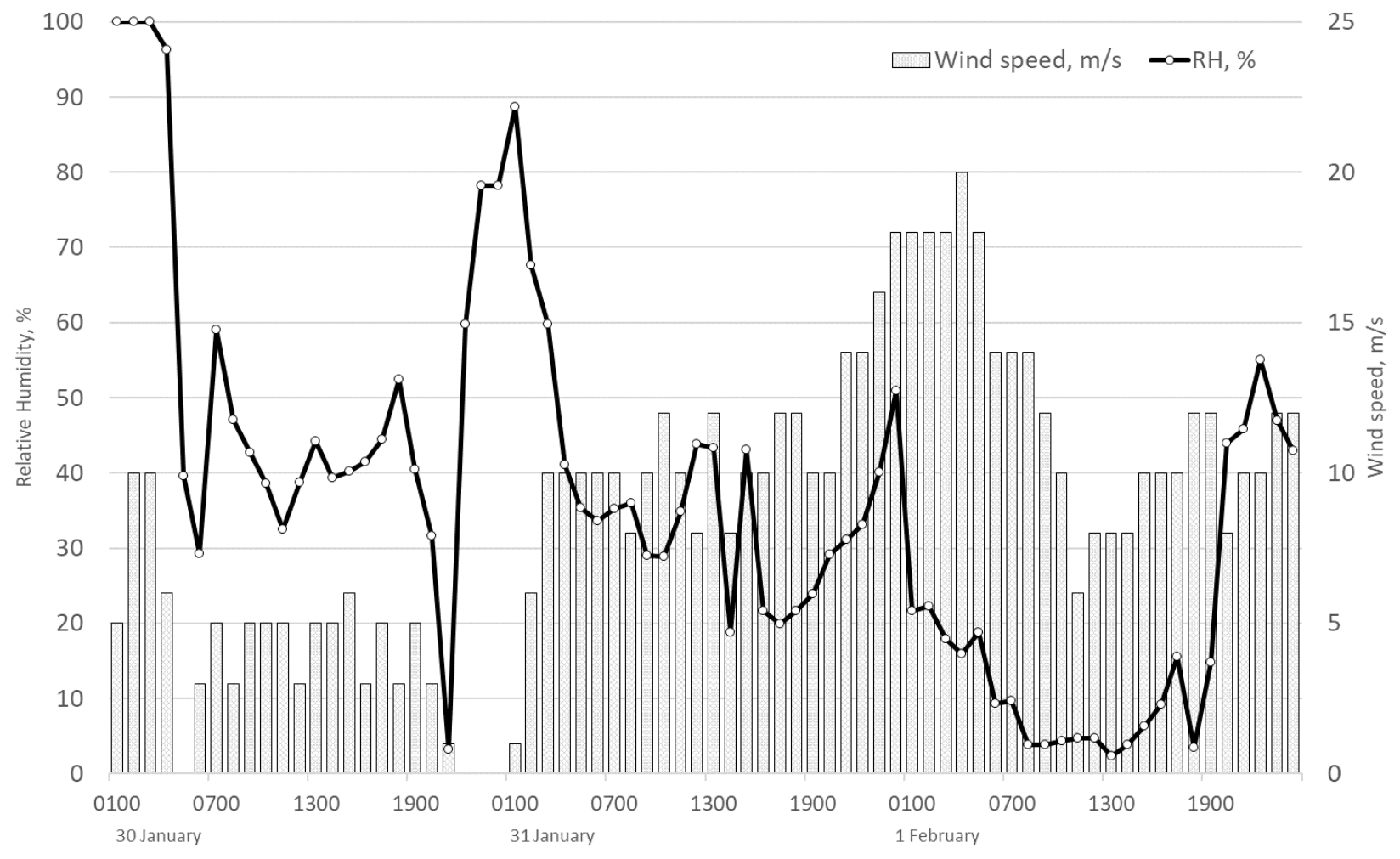


Figure 12. Skew-T plot of the upper-air sounding from Camborne in south-west England for 1200 UTC on 21 March 2018 showing a very marked anticyclonic subsidence inversion at $883 \mathrm{hPa}$.

Courtesy of the University of Wyoming.

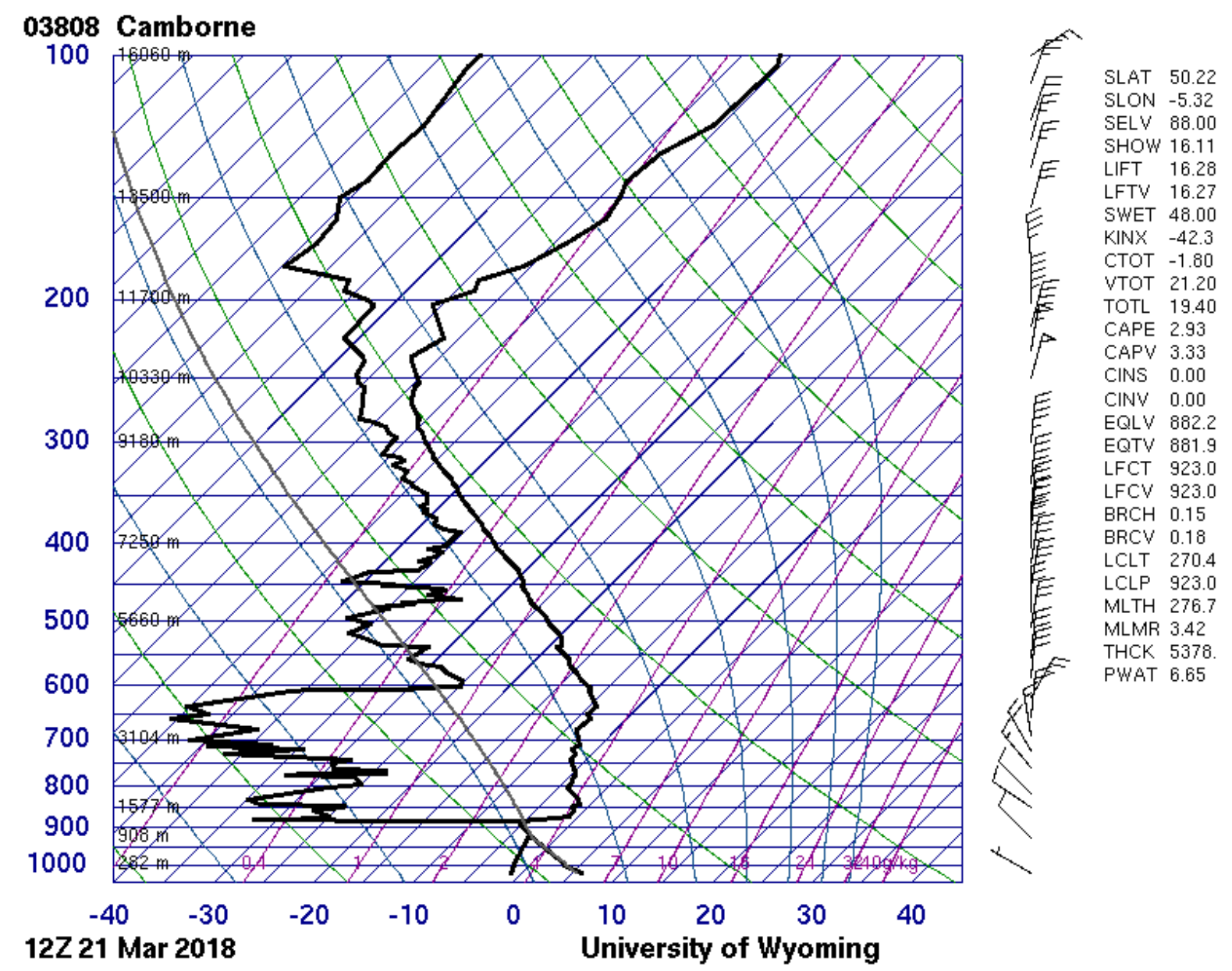

